J. Amer. Soc. Hort. Sci. 120(2):228-234. 1995.

\title{
Interaction of Root Confinement and Fruiting in Peach
}

\author{
Othmane Mandre \\ Ecole Nationale Superieure D'Horticulture, 4 Rue Hardy, RP 914, 78009, Versailles, Cedex, France
}

Mark Rieger and Stephen C. Myers

Department of Horticulture, University of Georgia, Athens, GA 30602

Ray Seversen
U.S. Department of Agriculture-Agricultural Research Service, Russell Research Center, Athens,
GA 30613
Jean-Luc Regnard
Laboratoire d'Arboriculture fruitère, Ecole Nationale Supèrieure Agronomique, 2, place Pierre Viala,
34060 Montpellier Cedex 1, France

Additional index words. Prunus persica, restricted root zone volume, $\mathrm{CO}_{2}$ assimilation, gas exchange, nonstructural

carbohydrates. photosynthesis

\begin{abstract}
Fruiting and nonfruiting 'Washington' peach trees were grown in 2.4 (small) or 9-liter (large) containers to determine the influence of root confinement and fruiting on vegetative growth, fruit growth and quality, $\mathrm{CO}$, assimilation (A), and carbohydrate content. Shoot length, fruit diameter, A, and leaf carbohydrates were measured weekly. Thirteen weeks after transplanting, trees were divided into roots, shoots, leaves, and fruit for dry weight measurement. The dry weight of all organs except fruit was reduced by root confinement, and only the weight of stems formed the previous season was not reduced by fruiting. Fruit dry weight was $30.0 \mathrm{~g} /$ tree for large- and small-container treatments, causing the yield efficiency ( $\mathrm{g}$ fruit/g total dry wt) to be $\mathbf{5 0 \%}$ higher for confined trees. Fruit red color, weight, and diameter were unaffected by root confinement, but higher flesh firmness and a more green ground color of the fruit surface from root-confined trees suggested that confinement delayed maturity. Vegetative growth was not reduced by lack of nonstructural carbohydrates in confined trees. A was reduced by root confinement on only the first of 11 measurement dates, whereas fruiting increased $A$ on 5 of 8 measurement dates before fruit harvest. Fruit removal reduced A by $23 \%$ and $31 \%$ for nonconfined and confined trees, respectively, within 48 h of harvest. Leaf starch, sucrose, sorbitol, and total carbohydrate levels were negatively correlated with A when data were pooled, but inconsistent responses of A to carbohydrate content indicated that factors other than feedback inhibition were also responsible for the reduction in $A$ on nonfruited trees. We hypothesized that a physiological signal originating in roots of confined trees reduced vegetativegrowth without reducing fruit growth.
\end{abstract}

Effective methods of size control for stone fruit trees are currently unavailable (Rom, 1983). Recent advances in semidwarf peach breeding offers a potential solution (Gradziel and Beres, 1993), but high-quality fresh-market cultivars have not yet been produced. In some areas of Europe, paclobutrazol is used to control growth and increase fruit size of peach (Regnard, personal observation), but this chemical has not been approved for use in most fruit growing areas of the world, including the United States. Recent studies indicate that root confinement reduces peach tree growth, while not negatively affecting fruiting efficiency (Myers 1992; Ran et al., 1992; Williamson and Coston, 1990). In addition, confinement of the root system to a small, well-defined soil volume may have other benefits like 1) increasing efficiency of irrigation and fertilizer use by targeting applications to tree roots, 2) controlling growth through deficit irrigation (Chalmers et al., 1981) in rainy climates where this technique could not otherwise be practiced, 3) reducing herbicide use via reduction in area of the weed-free zone beneath the trees, and 4) allowing fumigation for nematode and soilborne diseases due to the reduced soil volume that needs be treated (currently not cost-effective to treat entire orchard).

Received for publication 6 Apr. 1994. Accepted for publication 7 Sept. 1994. We thank Pat Mason and Susan Wilson for valuable assistance with carbohydrate analysts. The cost of publishing this paper was defrayed in part by the payment of pagecharges. Underpostal regulations, this paper therefore must be hereby marked advertisement solely to indicate this fact.
The physiological basis for tree size control by root confinement remains unclear, but carbon, nutrient, and water resources do not appear to he limiting (Rieger and Marra, 1994). Root confinement or competition sometimes reduces $\mathrm{CO}_{2}$ assimilation (A) (Hameed et al.. 1987; Marvel et al.. 1992; Robbins and Pharr, 1988), although in peach this was likely aconsequence, ratherthan a cause, of reduced growth (Rieger and Marra, 1994). Reduced A in root-confined plants was associated with Increased leaf carbohydrate content (Robbins and Pharr, 1988; Rieger and Marra, 1994), suggesting that feedback inhibition of photosynthetic products caused the reduction in A when sink strength was reduced. An analogous situation occurs when sink strength is altered by fruiting; the presence of fruit often increases A while reducing carbohydrate content of nearby leaves (Flare and Lakso, 1989; Lenz, 1979).

In this study, we confirm the responses of peach trees to root confinement previously reported by Rieger and Marra (1994) using older fruiting and nonfruiting trees. Using container-grown trees allowed examination of the interaction between fruiting and root confinement on growth and gas exchange and the influence of root confinement on fruit growth and quality. Furthermore, we wanted to determine whether the presence of an active sink (fruit) on a tree with confined roots could compensate for the reduction in root sink strength and how this may alter growth, gas exchange, leaf carbohydrate content, and the functional relationship between these variables. 


\section{Materials and Methods}

Plant material and growth conditions. Eighteen-month-old rooted cuttings of 'Washington' peach were transplanted from 2.4liter containers into either 2.4- (small) or 9-liter (large) containers using a commercial soilless medium (Fafard \#2, Springfield, Mass.) on 16 Apr. 1993. Trees were 50 to $75 \mathrm{~cm}$ tall and had open and post-bloom flowers on the main stem. The large- and smallcontainer treatments each contained 16 trees, which were subdivided into fruiting and nonfruiting classes (with 8 trees in each) a few days after transplanting by removing fruit and flowers from half the plants. This gave a factorial arrangement of 2 container volumes $\times 2$ fruiting classes, hereafter referred to as LF (large, fruiting), LNF (large, nonfruiting), SF (small, fruiting), and SNF (small, nonfruiting). Fruiting trees were thinned to one to three fruit/tree, depending on tree size, with larger trees carrying more fruit. Two trees exhibiting poor growth were removed from the study after 2 weeks, giving seven single-tree replications in the LNF and SNF treatments and eight replications in the LF and SF treatments.

Trees were arranged on two greenhouse benches in a completely randomized design and grown for 13 weeks, until 1 week after fruit were harvested. Growth conditions were light at $70 \%$ of daily integrated solar radiation, temperature minima and maxima of $\approx 15$ and $35 \mathrm{C}$, respectively, and humidity near ambient. Water and nutrients were supplied with an automated drip system using a soluble fertilizer (20N-8.6P-12K plus trace elements). The injection rate was adjusted to yield a solution conductivity of 0.40 to $0.50 \mathrm{dS} \cdot \mathrm{m}^{-1}$ at the dripper, and enough solution was applied so that leachate conductivity was the same. Trees were irrigated once per day initially, but frequency was increased to three times daily for small containers and two times daily for large containers as demand for water increased during the study.

Measurement of growth. Five shoots on each tree were tagged at the outset, and their lengths were measured to the nearest millimeter weekly. On fruiting trees, fruit diameter was measured with a digital caliper weekly. Shoot and fruit growth rates were calculated by taking the difference of consecutive weekly measurements, giving units of $\mathrm{cm} /$ week and $\mathrm{mm} /$ week, respectively. Fruit were harvested from fruiting trees 81 days after transplanting, and diameter, percent red color, ground color (using color chips; Delwiche and Baumgardner, 1983), weight, and firmness of each fruit were determined. Trees were divided into leaves, current-season shoots, older shoots, and roots 1 week after fruit removal. Tissues were dried at $80 \mathrm{C}$ to determine dry weight.

Net $A$ and nonstructural carbohydrate measurement. Net A was measured weekly beginning 5 weeks after transplanting using a portable photosynthesis meter (Li-6200; Li-Cor, Lincoln, Neb.).
Measurements were made between 1100 and 1300 HR when photosynthetic photon flux density was $>1000 \mu \mathrm{mol} \cdot \mathrm{m}^{-2} \cdot \mathrm{s}^{-1}$. The most recently expanded leaf on an upright shoot (generally $>5$ nodes below the terminal bud) was selected for measurement. The frequency of A measurement was increased to $48 \mathrm{~h}$ during the week after fruit removal to follow short-term changes in A following harvest. Immediately following A measurement, the leaf was detached, placed in a plastic bag on ice, transported to the lab, and frozen within $1 \mathrm{~h}$ at $-18 \mathrm{C}$. The nonstructural carbohydrates fructose, glucose, sucrose, sorbitol, and starch were measured as described previously (Rieger and Marra, 1994) on $\approx 100 \mathrm{mg}$ of freeze-dried leaf tissue.

\section{Results}

Growth. Total dry weight was reduced $\approx 30 \%$ by a 3.75 -fold reduction in container volume regardless of the presence or absence of fruit (Table 1). Root confinement reduced dry weight of all plant organs except fruit, whereas fruiting reduced weights of all organs except older shoots. Fruit weight per tree was unaffected by root confinement, resulting in increased percent dry matter allocation to fruit on trees in small pots. Relative to LF trees, SF trees had a $57 \%$ greater fruiting efficiency (dry weight fruit/total dry weight). This agrees with previous reports that yield efficiency is increased by root confinement in peach (Myers, 1992; Williamson and Coston, 1990), bell pepper (Nesmith et al., 1992), and cotton (Carmi and Shalhevet, 1983).

Root : shoot ratio was reduced by root confinement and fruiting, and a significant interaction indicated that a greater reduction in root : shoot ratio due to root confinement occurred in nonfruiting than fruiting trees (Table 1). This result disagrees with that found in previous studies on peach (Ran et al., 1992; Richards and Rowe, 1977; Rieger and Marra, 1994) and herbaceous species (Nesmith et al., 1992; Robbins and Pharr, 1988; Ruff et al., 1987), where root : shoot ratio was either unaffected or increased by root confinement.

Shoot length was reduced by root confinement on all measurement dates, and growth rates were affected on all but two dates (Fig. 1). This agrees with a previous study in which shoot growth was affected very early in the growth cycle by root confinement (Rieger and Marra, 1994). The presence of fruit caused a reduction in shoot length until week 11, or 1 week before harvest (Fig. 1). Shoot growth rates were variable, but generally higher for nonconfined trees early in the study and higher for SF trees on the last two measurement dates.

Fruit diameter was reduced by root confinement only during weeks 4 to 6 after transplanting (5 to 7 weeks after bloom), whereas final fruit size and growth rate were not affected (data not shown). Fruit quality parameters affected by root confinement were firm-

Table 1. Dry weight partitioning of 'Washington' peach trees 13 weeks after transplanting to 2.4-liter (small) or 9-liter (large) containers.

\begin{tabular}{|c|c|c|c|c|c|c|c|}
\hline \multirow[b]{2}{*}{ Treatment } & \multicolumn{6}{|c|}{ Dry wt, g (\% of total dry wt) } & \multirow[b]{2}{*}{ Root : shoot ratio } \\
\hline & Leaves & Current stems & Old stems & Roots & Fruit & Total & \\
\hline Large, +fruit & $78(37)$ & $23(11)$ & $41(19)$ & $42(19)$ & $30(14)$ & 214 & 0.24 \\
\hline Large, -fruit & $86(41)$ & $30(14)$ & $38(18)$ & $55(26)$ & 0 & 209 & 0.36 \\
\hline Small, +fruit & $53(38)$ & $11(8)$ & $25(18)$ & $21(\mathrm{E})$ & $30(22)$ & 140 & 0.18 \\
\hline Small, -fruit & $73(48)$ & $20(13)$ & $33(22)$ & $28(18)$ & 0 & 154 & 0.22 \\
\hline \multicolumn{8}{|l|}{ Significance $^{z}$} \\
\hline $\mathrm{V}$ & 0.0003 & 0.0002 & 0.0008 & 0.0001 & 0.9935 & 0.0001 & 0.0001 \\
\hline $\mathrm{F}$ & 0.0065 & 0.0033 & 0.4717 & 0.0005 & - & 0.6930 & 0.0001 \\
\hline I & 0.1780 & 0.6247 & 0.0728 & 0.2507 & --- & 0.3765 & 0.0025 \\
\hline
\end{tabular}

${ }^{7} P>$ F value for the main effects of container volume $(\mathrm{V})$, fruiting $(\mathrm{F})$, and their interaction $(\mathrm{I})$. 


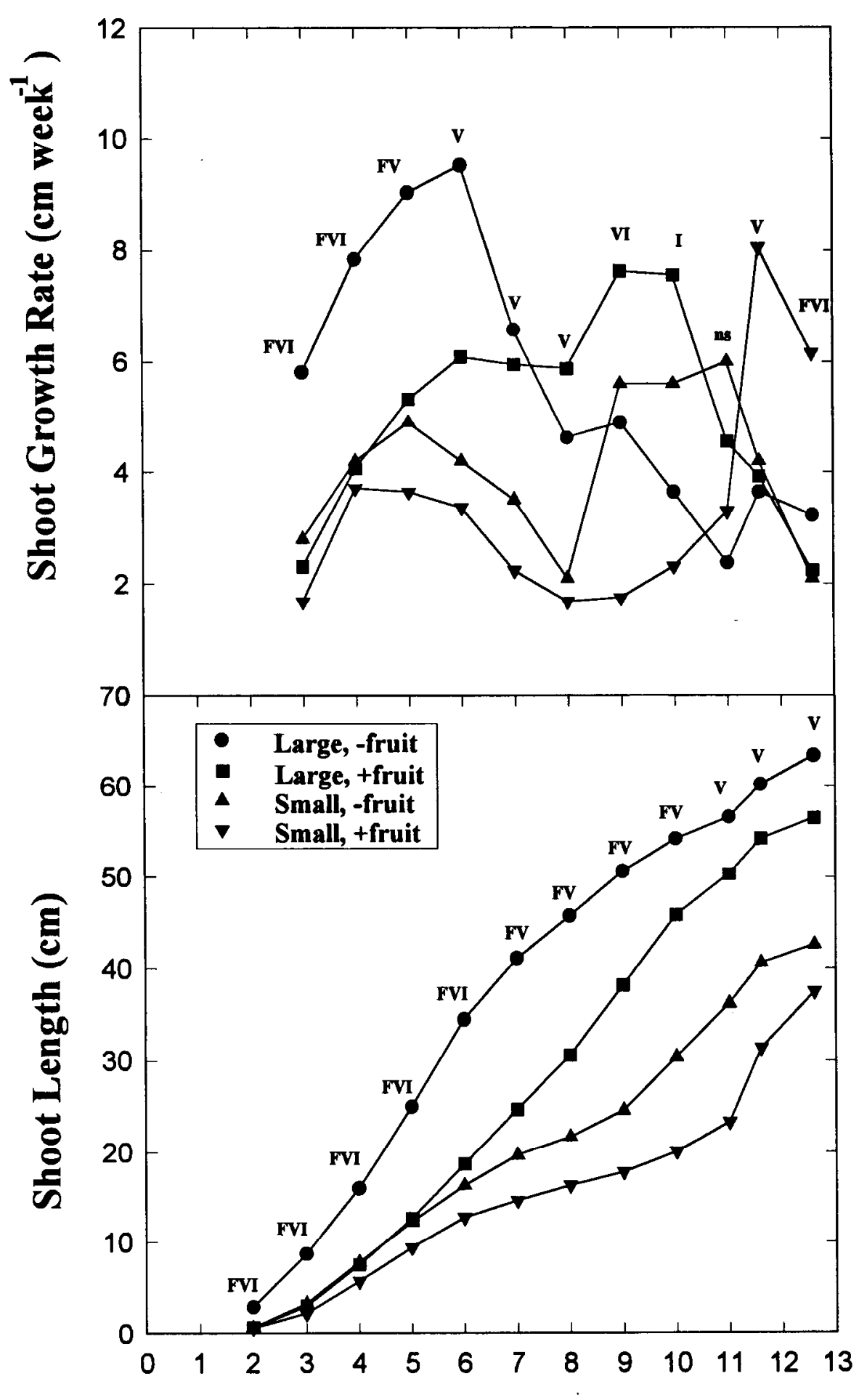

Weeks After Transplanting

Fig. 1. Shoot length and shoot growth rate of trees in 9-liter containers with and without fruit (large, +fruit, and large, -fruit, respectively), and 2.4-liter containers with and without fruit (small, +fruit, and small, -fruit, respectively). On each measurement date, significance of the treatment effects is shown by letters above the uppermost symbol in each graph: $\mathrm{F}=$ main effect of fruiting significant; $\mathrm{V}=$ main effect of container volume significant; $\mathrm{I}=$ interaction between fruiting and container volume significant; $\mathrm{ns}=$ nonsignificant main effects and interactions $(P<0.05)$.

tress and ground color, with more firm fruit (35 vs. 15 Newtons, $P$ $<0.05$ ) with more green ground color (color chip 1.9 vs. $4.3, P<$ $0.05)$ from confined than nonconfined trees. Thus, root confinement appeared to delay fruit maturity by a few days, but did not change fresh weight, dry weight, diameter, or percent red color.
This differs from Myers' (1992) results, which showed that root confinement advanced peach maturity.

Net $A$ and nonstructural carbohydrates. Root confinement reduced $\mathrm{A}$ on only the first of eleven measurement dates, whereas fruiting trees had higher A than nonfruiting counterparts on five of 
eight dates before harvest (Fig. 2). A was not affected by treatments during weeks 7 to 9 , a period corresponding to relatively low fruit growth rates (late pit-hardening period). A was linearly correlated $(r=0.83, P<0.05)$ with fruit growth rate for the SF treatment, but this correlation was nonsignificant $(P>0.05)$ for the LF treatment.

A was similar for nonfruiting and previously fruited trees $48 \mathrm{~h}$ after fruit removal, as defruiting reduced $\mathrm{A}$ by $23 \%$ and $31 \%$ for LF and SF trees, respectively (Fig. 2). Environmental conditions during measurement were similar on these dates. Sucrose, starch and total carbohydrates were lower for fruiting than nonfruiting trees at harvest when A was higher for fruiting trees (Table 2, Fig. 2 ). However, there were no significant differences in carbohydrates between fruiting and nonfruiting trees $48 \mathrm{~h}$ after fruit removal when A was similar among treatments. This suggests a role for feedback inhibition of sucrose and/or starch on A for confined trees, as suggested previously (Rieger and Marra, 1994). When data were pooled across all dates and treatments, A was negatively correlated with sorbitol, starch, sucrose, and total carbohydrate concentrations, but not with glucose or fructose (Fig. 3).

Nonstructural carbohydrates generally comprised $20 \%$ to $33 \%$ of leaf dry weight, increasing slightly over time, with sorbitol being $30 \%$ to $50 \%$ of the total (data not shown). Carbohydrate concentrations, particularly sorbitol, were much higher than those reported previously for peach (Rieger and Marra, 1994; Rom and Ferree, 1983, a result that may have been due to differences in growth conditions or cultivars used among these studies. The quantities of sorbitol found here were verified by high-performance liquid chromatography analysis on randomly selected samples at another laboratory (J. Flore, Michigan State Univ.).
Values for fructose and sucrose reported here were at least 2-fold higher than values obtained at the other laboratory. Reasons for differences between laboratories for these two sugars are unknown, but do not preclude a comparison of the relative effects of treatments.

There were very few interactions between pot volume and fruiting on leaf carbohydrate concentration; therefore, only the main effects of these variables are discussed. Data for week 12 (Table 2) were qualitatively representative of data from other dates where carbohydrates were affected by pot volume. Sucrose was higher in confined than nonconfined trees on five of nine dates measured, and on three of those dates, glucose and fructose were lower in confined trees (data not shown). As sucrose is composed of one glucose and one fructose molecule, this may suggest enhanced conversion of glucose and fructose to sucrose in confined trees, a reaction that occurred regardless of presence or absence of fruit. Starch was lower for confined than nonconfined trees on weeks 9,10 , and 11, and total carbohydrates were lower for confined trees on weeks 9 and 11. Glucose and sorbitol were higher for confined than nonconfined trees $48 \mathrm{~h}$ after harvest (Table 2); this is in contrast to the effect of pot volume on these carbohydrates seen on other dates.

Fruiting generally caused a reduction in leaf carbohydrates when significant effects occurred (data not shown) regardless of pot volume. Glucose, fructose, and sorbitol were affected by fruiting more frequently than other compounds, where higher concentrations were found on three of nine measurement dates in nonfruiting than fruiting trees. As sorbitol is the major carbohydrate translocated, this suggests that carbon export out of leaves was lower for nonfruiting than fruiting trees.

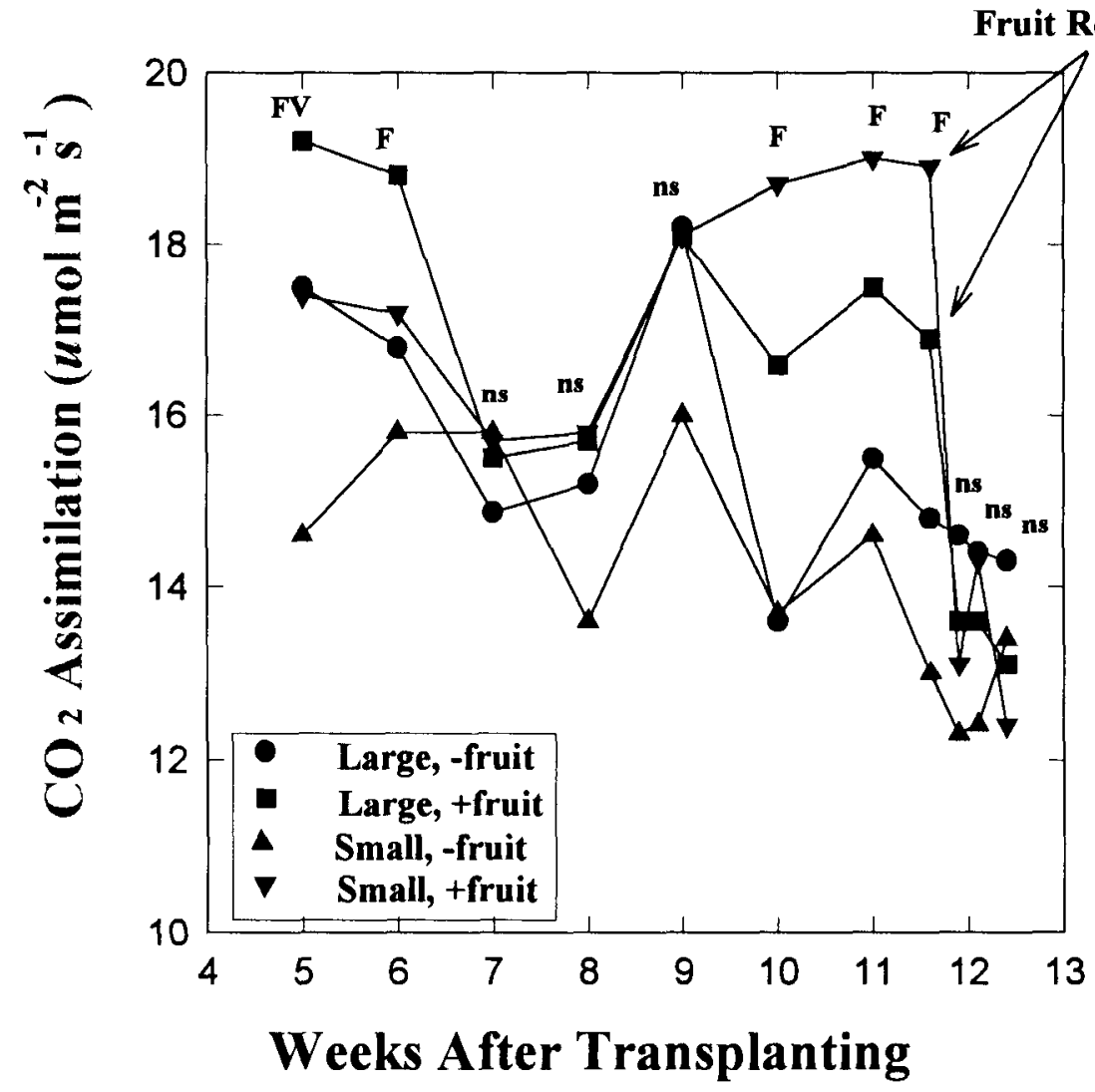

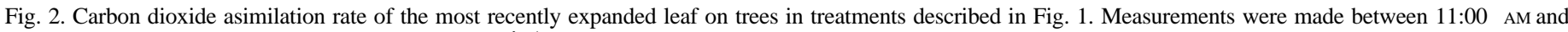
$1: 00 \mathrm{PM}$ with irradiance at leaf level $\geq 1000 \mu \mathrm{mol} \cdot \mathrm{m}^{-2} \cdot \mathrm{s}^{-1}$ Significance denoted by letters asexplained in Fig. 1. Fruit were removed 81 days after transplanting, as indicated by the arrows. 
Table 2. Concentration of carbohydrates in leaves $\left(\mathrm{mg} \cdot \mathrm{g}^{-1}\right.$ dry weight) of 'Washington' peach trees 12 weeks after transplanting when fruit were harvested and $48 \mathrm{~h}$ following harvest.

\begin{tabular}{|c|c|c|c|c|c|c|}
\hline Treatment & Fructose & Glucose & Sucrose & Sorbitol & Starch & Total \\
\hline \multicolumn{7}{|c|}{ Harvest } \\
\hline Large, +fruit & 54.5 & 32.4 & 19.2 & 125 & 53.7 & 284 \\
\hline Large, -fruit & 46.5 & 30.5 & 23.8 & 106 & 120 & 327 \\
\hline Small, +fruit & 30.9 & 24.3 & 28.4 & 101 & 18.0 & 202 \\
\hline Small, -fruit & 34.4 & 24.2 & 39.7 & 111 & 67.2 & 276 \\
\hline \multicolumn{7}{|l|}{ Significance $^{2}$} \\
\hline $\mathrm{V}$ & 0.0004 & 0.0077 & 0.0002 & 0.0961 & 0.0050 & 0.0002 \\
\hline $\mathrm{F}$ & 0.6349 & 0.7248 & 0.0079 & 0.4933 & 0.0004 & 0.0009 \\
\hline I & 0.2169 & 0.7348 & 0.2427 & 0.0289 & 0.5439 & 0.3258 \\
\hline \multicolumn{7}{|c|}{$48 \mathrm{~h}$ after harvest } \\
\hline Large, +fruit & 28.2 & 20.4 & 34.3 & 113 & 64.1 & 260 \\
\hline Large, -fruit & 32.7 & 23.0 & 29.3 & 113 & 71.0 & 269 \\
\hline Small, +fruit & 39.5 & 28.9 & 30.9 & 117 & 54.4 & 270 \\
\hline Small, -fruit & 35.4 & 24.6 & 34.6 & 124 & 59.2 & 278 \\
\hline \multicolumn{7}{|l|}{ Significance } \\
\hline $\mathrm{V}$ & 0.0710 & 0.0274 & 0.7718 & 0.0027 & 0.4103 & 0.4402 \\
\hline $\mathrm{F}$ & 0.9629 & 0.7086 & 0.7698 & 0.0955 & 0.6503 & 0.5093 \\
\hline I & 0.2709 & 0.1419 & 0.0629 & 0.1196 & 0.9381 & 0.9472 \\
\hline
\end{tabular}

${ }^{P} P>\mathrm{F}$ value for the main effects of container volume $(\mathrm{V})$, fruiting $(\mathrm{F})$, and their interaction (I).

\section{Discussion}

Growth. Fruit growth was less sensitive to root confinement than vegetative growth, because fruit size and growth rate were unaffected by confinement, whereas shoot growth rate and length were nearly always reduced by confinement. Thus, factors associated with confined roots appear to affect growth potential of fruit and stem tissues differently. Across all treatments, shoot and fruit growth rates were not correlated with individual or total carbohydrate contents (data not shown). Therefore, vegetative growth was reduced by factors other than carbon resources. Growth regulators have been implicated in the control of shoot growth by root confinement (Carmi and Heuer, 198 1; Richards and Rowe, 1977). If so, one explanation may be that fruit are able to produce their own growth regulators and maintain growth independent of a down-regulation of vegetative tissue expansion elsewhere in the plant.

The presence of an active sink (fruit) on root-confined trees did not result in greater dry weight accumulation relative to nonfruited, confined trees, despite higher A for fruiting trees. Thus, the presence of a fruit sink for photosynthate did not compensate for a presumed loss of sink strength of roots due to root confinement in terms of total dry matter accumulation. As such, it appears that dry weight accumulation was better related to root zone volume than the type of sink available. One explanation may be that, whether confined or nonconfined, dry matter was diverted from leaves to fruit, and this loss of photosynthetic surface was offset by an increase in assimilation rate per unit leaf, allowing fruiting and nonfruiting trees to achieve the same total dry weight.

Fruit weight was derived at the expense of all organs except older stems in confined trees; current-season stem and leaf weights were reduced proportionately more than weights of roots. Thus, root confinement may reduce the need for pruning and decrease within-canopy shading without adversely affecting fruit yield or quality. The primary objective of growth control is therefore achieved, similar to the effect that dwarfing rootstocks have on pome fruits.

The relative effect of fruiting on shoot length diminished throughout the study. Fruiting affected shoot length to a greater extent in nonconfined than confined trees during the first 5 weeks of the study, when there was a significant interaction (Fig. 1). However, shoot length was not affected by fruiting during week 11 or 12, despite high fruit growth rates at that time. This may indicate that competition for carbon resources between fruit and vegetative organs is greatest early in the growth cycle. As leaf area developed and carbohydrate status improved during the study, competition for carbon resources may have become gradually less limiting for shoot growth.

Carbon partitioning among organs was affected by root confinement and fruiting, unlike previous reports for peach (Ran et al., 1992; Rieger and Marra, 1994). Root : shoot ratio was decreased by the presence of fruit, yet fruiting trees had a smaller percentage reduction in root : shoot ratio due to root confinement than nonfruiting trees (Table 1). This suggests that the presence of fruit helps to stabilize the balance between root and shoot growth during root confinement stress, although it is unclear how this is achieved. Inconsistency in reports of the root confinement effect on carbon partitioning may result from differences in the period of growth when destructive sampling was performed. For example, root : shoot ratios change naturally with plant age and development (Milthorpe and Moorby, 1979), and it seems reasonable that experiments that differ in duration, plant species, and growing conditions may produce different results as a consequence of time of sampling. Long-term field studies on root confinement are necessary to determine the consequences, if any, of changes in carbon partitioning among vegetative organs as seen in short-term studies on containerized plants such as this one. Nevertheless, increased carbon allocation to reproductive organs during root confinement as reported here also occurs under field conditions (Ben-Porath and Baker, 1990; Carmi et al., 1983; Myers, 1992; Williamson and Coston, 1990).

Net $A$ and nonstructural carbohydrates. Root confinement reduced A only on the first measurement date, just after the first leaves became fully expanded. It is unclear if A was affected before week 5 because the assimilation cuvette could not accomodate leaves before this date. However, an early reduction followed by 


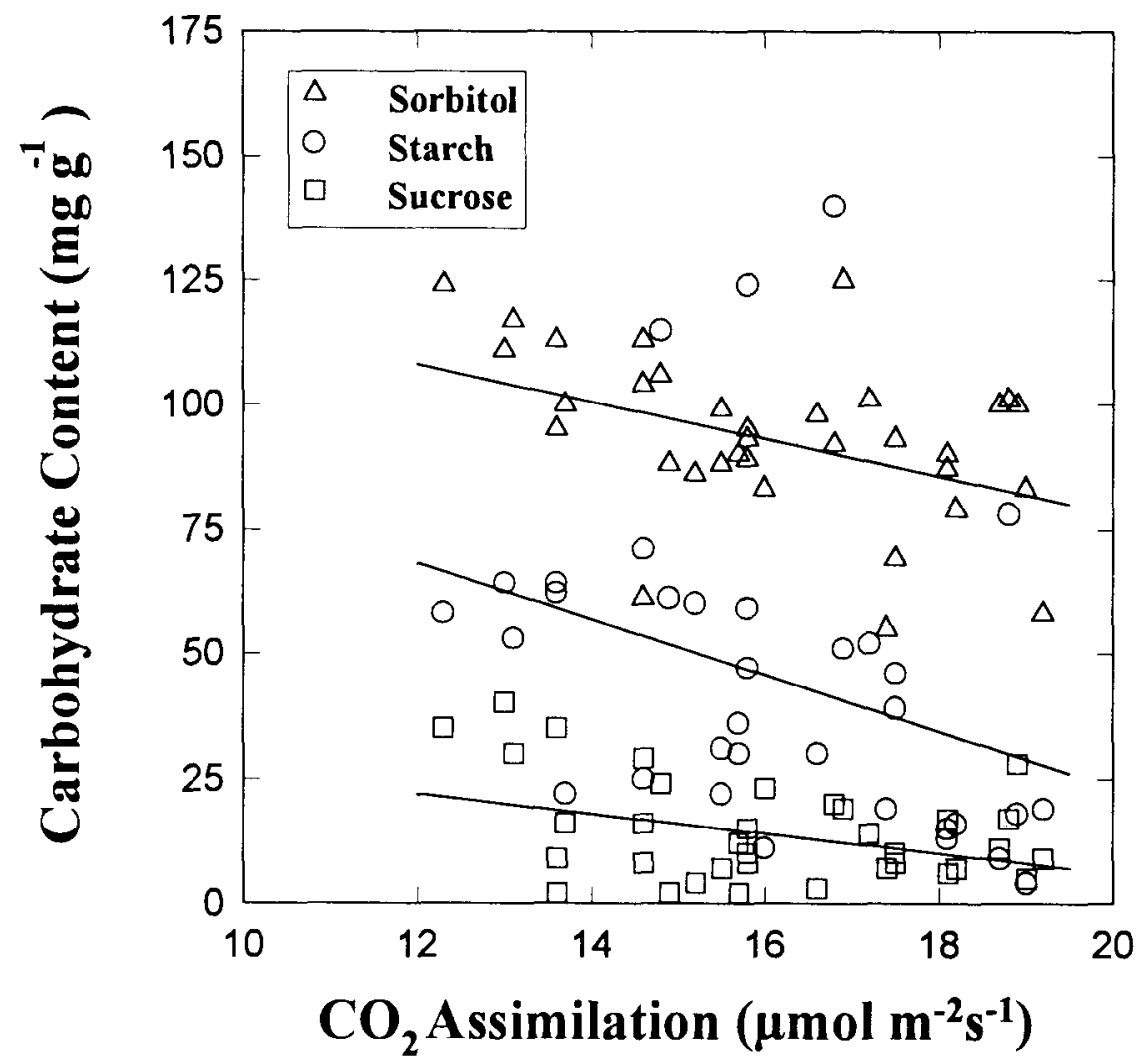

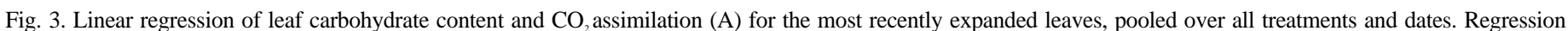

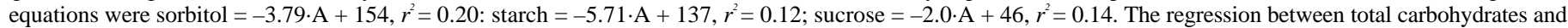
A (not shown) was also significant $\left(P<0.05 . r^{2}=0.21\right)$. All slopes and intercepts different from $0,5 \%$ level. Regressions for glucose and fructose were nonsignificant.

recovery in A was also previously reported, when whole-plant photosynthesis was measured beginning 2 weeks after budbreak (Rieger and Marra, 1994). In our study, root confinement probably did not reduce shoot growth through a reduction in carbon resources, as total carbohydrates were reduced by root confinement on only two out of nine measurement dates (not shown) and A was similar for confined and nonconfined trees, yet shoot growth rate was affected by confinement on all but two dates (Fig. 1). Similar responses of gas exchange to root confinement in separate studies indicate that A may be affected very early in plant development, but then may recover to normal levels later, whereas vegetative growth is affected early and permanently by root confinement. The recovery of $\mathrm{A}$ in root confined trees may represent a return to balanced carbon acquisition following an initial adjustment prompted by the onset of the root confinement stress.

It is unclear why A was correlated with fruit growth rate for only confined trees. As shoot growth was greater in LF trees, the leaves used for A measurement were relatively farther from the fruit than for SF trees. This closer coupling of A and fruit growth rate in SF trees might have been a function of closer proximity of the measured leaf to fruit than for LF trees. It is known that most of the carbohydrates imported by fruit arc synthesized in the nearest leaves (Westwood, 1993), and, with some evidence of feedback inhibition of carbohydrates on A across treatments (Fig. 3), a greater response of $\mathrm{A}$ to fruit growth in confined trees may be expected. Alternatively, a greater leaf : fruit ratio for LF than SF trees may have decreased the coupling of A to fruit growth for nonconfined trees.

The variation over time (or plant development) in the response of A to root confinement may explain the lack of agreement in literature on this point. Root confinement was associated with increases (Carmi et al.. 1983), decreases (Hameed et al., 1987; Robbins and Pharr, 1988) and nonsignificant effects on A or net assimilation rate (NAR) (Krizek et al., 1985; Ruff et al., 1987). However, in only one of these studies was A or NAR measured more than once (Carmi et al., 1983), and in this case the response of A to root confinement varied with time. Reductions in growth in all cases were associated with reduced leaf area on plants with confined roots regardless of influences on A. The greater impact of reduced leaf area rather than A on growth of root-confined plants was illustrated by NeSmith et al. (1992), where whole-plant photosynthesis was reduced to a greater extent by root confinement than single-leaf photosynthetic rate. Since only single leaves of uniform age were measured in our study, it is unclear if A of other leaves was affectedby root confinement, perhaps contributing to altered growth. However, agreement between our data and that from previous studies measuring whole-plant A (Rieger and Marra, 1994) suggests that growth in peach was not limited by photosynthetic rate.

The fruit effect on A was eliminated $48 \mathrm{~h}$ after fruit removal (Fig. 2), similar to the response of cherry to defruiting (Gucci et al., 199 1). The decrease in A between harvest and harvest $+48 \mathrm{~h}$ was significant $(P<0.05)$ for fruiting plants in both container volumes, yet A was similar on these dates for nonfruiting trees. Overall, A was negatively correlated with sorbitol, sucrose, starch, and total carbohydrates (Fig. 3). These data, and the data in Table 2 argue in favor of feedback inhibition of carbohydrates on A. However, there were many inconsistencies in the relationship between carbohydrates and $\mathrm{A}$ on other measurement dates (not presented); for example, on only three of the five dates when A was increased by fruiting was there a concommitant decrease in total carbohydrates in fruiting trees. As $r^{2}$ values were quite low (Fig. 3), factors related 
to fruiting other than feedback inhibition must also be involved in the elevation of A by the presence of fruit. Fruit are rich sources of growth regulators, such as gibberellic acid, cytokinins, and auxin (Salisbury and Ross, 1985; Westwood, 1993), which are known to increase A (Roper and Williams, 1989; Lenz, 1979). These compounds may cause the fruit effect in leaves and maintain fruit cell extensibilities (and thus growth rates) against a possible negative signal coming from roots in confined plants (Cosgrove and Sovonick-Dunford, 19X9).

Similarities between this and a previous study (Rieger and Marra, 1994) suggest the following:

1) The most sensitive response to root confinement of those measured was shoot extension. As this is also a rapid and nondestructive measurement and closely correlated to leaf expansion, future work on root confinement should include this variable.

2) Growth of confined trees was not reduced by lack of carbohydrates. Growth of root-confined plants appears to be regulated by lower sink utilization of carbon resources and reduced leaf area, not reduced assimilation on a leaf area basis.

3) Evidence for feedback inhibition of carbohydrates on A was found in both studies, but inconsistencies in these data cast doubt on this as the sole mechanism controlling A in confined vs. unconfined and fruiting vs. nonfruiting plants.

This study further shows that carbon is preferentially taken from current shoot growth to support fruiting in confined plants and agrees with previous studies on peach demonstrating an increase in yield efficiency with root confinement. The physiological mechanism that reduces shoot growth without negatively affecting fruit growth merits further investigation, as this may have tremendous implications for tree crop management.

\section{Literature Cited}

Ben-Porath, A. and D.N. Baker. 1990. Taproot restriction effects on growth, earliness, and dry weight partitioning of cotton. Crop Sci. 30:809-814.

Carmi, A., J.D. Hesketh, W.T. Enos, and D.B. Peters. 1983. Interrelationships between shoot growth and photosynthesis, as affected by root growth restriction. Photosynthetica 17:240-245.

Carmi, A. and B. Heuer. 1981 The role of roots in control of bean shoot growth. Ann. Bot. 48:519-527.

Carmi, A. and J. Shalhevet. 1983. Root effects on cotton growth and yield. Crop Sci. 23:875-878.

Chalmers, D.J., P.D. Mitchell, and L. van Heek. 1981. Control of peach tree growth and productivity by regulated water supply, tree density, and summer pruning. J. Amer. Soc. Hort. Sci. 106:307-312.

Cosgrove, D.J. and S.A. Sovonick-Dunford. 19X9. Mechanism of gibberellin-dependent stem elongation in peas. Plant Physiol. 89:184-191.

Delwiche, M.J. and R.A. Baumgardner. 1983. Ground color measure- ments of peach. J. Amer. Soc. Hort. Sci. 108:1012-1016.

Flore, J.A. and A.N. Lakso. 19X9. Environmental and physiological regulation of photosynthesis in fruit crops. Hort. Rev. 11:111-157.

Gradzie1,T.M. and W. Beres. 1993. Semidwarf growth habit in clingstone peach withdesirable tree and fruit qualities. HortScience 28:1045-1047.

Gucci, R., P.D. Petracek, and J.A. Flare. 1991. The effect of fruit harvest on photosynthetic rate. starch content, and chloroplast ultrastructure in leaves of Prunus avium L. Adv. Hort. Sci. 5: 19-22.

Hameed, M.A., J.B. Reid, and R.N. Rowe. 1987. Root confinement and its effects on the water relations. growth and assimilate partitioning of tomato (Lycopersicon esculentum Mill.). Ann. Bot. 59:685-692.

Krizek, D.T., A. Carmi, R.M. Mirecki. F.W. Snyder, and J.A. Bunce. 1985. Comparative effects of soil moisture stress and restricted root zone volume on morphogenetic and physiological responses of soybean [Glycine max (L.) Merr.]. J. Expt. Bot. 36:25-38.

Lenz, F. 1979. Fruit effects on photosynthesis, light- and dark-respiration, p. 271-281. In: R. Marcelle, H. Clijstera, and M. van Pouke (eds.). Photosynthesis and plant development. Junk, The Hague.

Marvel, J.N., C.A. Beyrouty, and E.E. Gbur. 1992. Response of soybean growth to root and canopy competition. Crop Sci. 32:797-X01.

Milthorpe, F.L. and J. Moorby. 1979. An introduction to crop physiology. 2nd ed. Cambridge Univ. Press, Cambridge, U.K. p. 195.

Myers, S.C. 1992. Root restriction of apple and peach with in-\&round fabric containers. Acta Hort. 322:215-219.

NeSmith, D.S., D.C. Bridges, and J.C. Barbour. 1992. Bell pepper responses to root restriction. J. Plant Nutr. 15:2763-2776.

Ran, Y., B. Bar-Yosef, and A. Erez. 1992. Root volume influence on dry matter production and partitioning as related to nitrogen and water uptake rates by peach trees. J. Plant Nutr. 15:713-726.

Richards, D. and R.N. Rowe. 1977. Effects of root restriction root pruning and 6-benzylaminopurine on the growth of peach seedlings. Ann. Bot. 41:729-740.

Rieger, M. and F. Marra. 1994. Responses of young peach trees to root confinement. J. Amer. Soc. Hort. Sci. 119:223-228.

Robbins, N.S. and D.M. Pharr. 1988. Effect of restricted root growth on carbohydrate metabolism and whole plant growth of Cucumis sativus $\mathrm{L}$. Plant Physiol. 87:409-413.

Rom, R.C. 1983. The peach rootstock situation: an international perspective. Fruit Var. J. 37(1):3-14.

Rom, C.R. and D.C. Ferree. 1985. Time and severity of summer pruning influences on young peach tree net photosynthesis, transpiration, and dry weight distribution. J. Amer. Soc. Hort. Sci. 110:455-461.

Roper, T.R. and L.E. Williams. 1989. Net $\mathrm{CO}_{2}$ assimilation and carbohydrate partitioning of grapevine leaves in response to trunk girdling and gibberellic acid application. Plant Physiol. 89: 1136-1140.

Ruff, MS., D.T. Krizek, R.M. Mirecki, and D.W. Inouye. 1987. Restricted root zone volume: Influence on growth and development of tomato. J. Amer. Soc. Hort. Sci. 112:763-769.

Salisbury, F.B. and C.W. Ross. 1985. Plant physiology. 3rd ed. Wadsworth Publishing Co., Belmont. Calif. p. 333.

Westwood, M.N. 1993. Temperate-zone pornology. 3rd ed. Timber Press, Portland, Ore. p. 248.

Williamson, J.G. and D.C. Coston. 1990. Planting method and irrigation rate influence vegetative and reproductive growth of peach planted at high density. J. Amer. Soc. Hort. Sci. 115:207-212. 